\title{
MOTYW MELANCHOLII W CZESKIEJ AWANGARDOWEJ POEZJI WIZUALNEJ NA PRZYKLADZIE UTWORU NA JEHLÁCH TĚCHTO DNÍ JINDŘICHA HEISLERA I JINDŘICHA ŠTYRSKIEGO
}

\author{
Melancholy in Czech Visual Avant-garde Poetry on the Example of \\ Na jehlách těchto dní by Jindřich Štyrský and Jindřich Heisler
}

Keywords: melancholy, surrealism, Jindřich Štyrský, Jindřich Heisler

Contact: Uniwersytet Wrocławski; brzezinska.ann@gmail.com, anna.brzezinska@uwr.edu.pl; ORCID: https://orcid.org/0000-0003-2829-4023

\begin{abstract}
Wstęp
Melancholia jest jednym $\mathrm{z}$ najstarszych i najbardziej utrwalonych toposów występujących w naszej kulturze. Jej definicje i przedstawienia zmieniały się dynamicznie na przestrzeni wieków. W sensie mitycznym oznaczana jest jako czarna żółć lub czarne słońce oraz jako smutek spowodowany narodzinami pod planetą Saturna. Od XIX w. badano ją przez pryzmat psychoanalizy jako jednostkę chorobową, objawową lub fenomenologiczną (Bieńczyk 2012: 6-21). Obecnie melancholia nie jest postrzegana jako zwyczajne przygnębienie. We współczesnym rozumieniu określana jest jako uczucie smutku z powodu przerwania jakiejś ciągłości i doświadczenia straty. Zasoby czasu i przestrzeni melancholika wydają się być bardzo ograniczone lub nienaturalnie zdeformowane. Teraźniejszość jest dla niego w dziwny sposób zagięta, urwana lub odwrotnie, wlecze się niepokojąco, dłuży się przez wieczność. Życie jawi się jako cykl powtórzeń, które stają się horrorem, ponieważ nie przewidują żadnego zakończenia. Melancholia to także żałoba, która nigdy nie została przepracowana; człowiek trwa więc w tych uczuciach mnożąc kolejne wspomnienia, często nienawidząc pożądanego obiektu (Bieńczyk 2012: 23-30).

Badacze czeskiej literatury awangardowej zwracają szczególną uwagę na to, że surrealistyczne dzieła powstałe przed lub w trakcie drugiej wojny światowej są przede wszystkim odbiciem społecznych lęków, atmosfery niepewności i braku ciągłości czasowej (Vojvodík 2007: 50-56). Być może jednak estetykę melancholii (w jej
\end{abstract}


szerokim rozumieniu) również $\mathrm{z}$ powodzeniem można przymierzyć do surrealistycznych utworów. Zakładając, że atmosfera lęku była podczas wojny przejmująca i ogarniająca wszystkie aspekty życia człowieka, to jednostka nie była w stanie uchronić swojej psychiki inaczej, niż tylko przez zastosowanie pewnych mechanizmów obronnych. Poczucie rezygnacji, niemożność działania i brak perspektywy, świadomość braku sprawstwa, czynniki te mogą spowodować pewnego rodzaju apatię i obojętność, co prowadzić może do melancholii czy depresji (Małczyńska 2010: 19-20).

\section{Na jehlách těchto dní (Na iglach tych dni) a motyw melancholii}

Przejmujący lęk, dziwnie zagięta oś czasowa, zaburzone postrzeganie świata, czekanie w bezruchu i odrętwieniu na coś, co nie nadejdzie, niepokojąca obecność rzeczy; wszystkie te motywy melancholii możemy odnaleźć w cyklu $\mathrm{Na}$ jehlách těchto dní ( $\mathrm{Na}$ igłach tych dni). Koncept stworzony został we współpracy Jindřicha Štyrskiego (fotografie) i Jindřicha Heislera (tekst) w roku 1941. Jindřich Heisler pisał o tym projekcie, że powstał w czasach, kiedy ,zwaliła się na nas ciężka i szarawa rtęć” (Heisler 1999b: 310), mając na myśli doświadczenie drugiej wojny światowej. Projekt artystów jest złożony z dwóch warstw - tekstowej i wizualnej. W pierwszej znalazł się opis miasta, pozostającego $\mathrm{w}$ dziwnym marazmie, zastygnięciu, w którym to przedmioty swoją obecnością jakby nawołują ludzi do działania, nie doczekując się ostatecznie żadnej reakcji. Na drugą warstwę składają się zdjęcia przedmiotów z przestrzeni miasta: wystaw sklepowych, zaniedbanych kątów czy brudnych ścian, przedmiotów związanych ze śmiercią (trumienki czy krzyże). Najczęściej jednak występują motywy podobne do surrealistycznego kolażu lub poezji, w których to obiekt przechodzi różne metamorfozy: sfotografowane są przedmioty przypominające ciało człowieka: protezy, manekiny, obrazki, figurki lub lalki.

\section{Wyliczenia jako kolaż, żywioł i poszukiwanie całości}

Dla melancholii charakterystyczną figurą retoryczną są powtórzenia i wyliczenia. Melancholik zadaje sobie pytania odnośnie całości, która wydaje się mu być fragmentaryczna lub niepełna. Enumeracja jest jakimś rodzajem strategii psychologicznej, która ma złożyć cząstki w harmonijną całość. Zabieg ten jednak jest z góry skazany na niepowodzenie, melancholii nie da się przełamać. Wyliczenia mają przynieść ulgę, stają się jednak pułapką, halucynacją słów bez znaczenia rzucanych na wiatr (Bieńczyk 2012: 42). 
Wyliczenia wpisują się także w surrealistyczną estetykę, szczególnie kolaży, zarówno w dziełach plastycznych, jak i literackich. Przedstawione części ujęte w formie enumeracji poszukują całości; nigdy jej jednak nie odnajdą lub okaże się być nienaturalną i przerysowaną, a jednocześnie jedyną, jaka może w tym czasie wojny zaistnieć:

(...) złowrogie węże mnożą się z każdej filiżanki herbaty, z każdej sztuki mebla, ze wszystkich przymrużonych oczu w momencie pocałunku (... $)^{1}$ (Heisler 1999a: 92).

Jej nieskończony smutek (...). Jej niezmierzona nuda (...). Jej wieczne nieszczęście (...). Jej tępy ból (Heisler 1999a: 108).

W Na jehlách těchto dní warstwa tekstowa składa się z wielu opisów, wyliczeń ujętych w formie zdań złożonych. Obrazują one miasto, które żyje dzięki obiektom w swojej przestrzeni (przedmioty są sprawcze i decyzyjne), ludzie pojawiają się sporadycznie, najczęściej są określeni jako grupa (dzieci, przechodniów), nie mają imion ani osobowości. Mieszkańcy nie zauważają, że miasto jest w ciągłym rozpadzie, chaosie, pochłonięte wojną:

(...) i powietrze z placu, poprzecinane przechodzącymi pod wiatr ludźmi zbiera z gzymsów swój wypoczęty kurz i układa go znów w inne ciche miejsca zwracające uwagę na tajemnice czystości (...) (Heisler 1999a: 90).

Nie ma nic bardziej dusznego niż wieczory wciśnięte do przestrzeni trumny i żadna radość nie zakryje jej demonów (Heisler 1999a: 100).

Lęk spowodowany okrucieństwami wojny sprawia, że przestrzeń czy podmiot przedstawiane są jako ściśnięte w sobie, zastygłe w grozie (Vojvodík 2007: 50-56). W tekście Heislera szczególną funkcję pełnią dwa żywioły: ziemia i powietrze. Powietrze jest duszne, pełne kurzu, stęchłe, roznosi zapachy pleśni czy fekaliów. Ziemię charakteryzuje ścisły związek z krwią, pyłem, mięsem i chorobami. Ciekawym jest, że żywiołem przypisanym melancholii jest właśnie ziemia, która swoją ciężką materią i konsystencją oraz absurdalną ilością, staje się metaforą czarnej żółci, magmy, wlokącego się czasu. Realistyczne przedstawienia przedmiotów łączą się z postrzeganiem rzeczy przez pryzmat przesadnej organiczności, pierwotności,

\footnotetext{
${ }^{1}$ Wszystkie thumaczenia utworu $N a$ jehlách těchto dní Jindřicha Heislera pochodzą od autorki niniejszego artykułu.
} 
powrotem do najniższego poziomu - poziomu ziemi. W ziemi też znajdują się wszystkie szczątki, prochy, jest to miejsce końca ludzkiej egzystencji (Bieńczyk 2012: 48-52).

Otrząsająca się ziemia pomału ściera ciężki kurz z tysiąckrotnymi gniazdek gnoju (Heisler 1999a: 124).

Krew spływa po trawie i zaschniętą krew wznosi wiatr (Heisler 1999a: 130).

\section{Ograniczone zasoby czasu i przestrzeni}

Melancholia, jako „choroba widzenia rzeczy, jakimi są” (Bieńczyk 2012: 48) silnie wpisuje się w omawiany projekt. Ten realizm rzeczy sprawia, że zauważamy kruchość, zagładę, chorobę i przypadkowość w każdym obiekcie, a lękiem napawa uświadomienie sobie nieodwracalności procesów rozpadu, którego odczucie dodatkowo potęguje przemijający czas i zmieniająca się przestrzeń (Bieńczyk 2012: 48).

(...) Parują ścieki z ulicy i wspinają się po piętrach, gdzie rozchodzi się zatęchły swąd pleśni (Heisler 1999a: 100).

Rosną i pęcznieją na wszystkie strony dzieci tych straszliwie chorych ludzi z szarotkami alpejskimi wyszytymi głęboko w mięsie, w mięsie, które tak okropnie rozkwita, jak wścieklizna (Heisler 1999a: 116).

Procesy te są również ujęte na zdjęciach Štyrskiego. Do projektu Na jehlách těchto dni zostały wybrane fotografie bez postaci, osoby znajdują się na jego zdjęciach niezwykle rzadko i mamy wrażenie, jakby nie mieli znaleźć się w kadrze. Ukazują dążenie do naturalistycznego wręcz przedstawienia obiektów znalezionych, ukazania rzeczywistości jako okrutnej, przemijającej, zniszczonej (Srp 2001: 41-42). Ma się wrażenie, że artysta partykularyzuje świat rzeczywisty, pozbawia go kontekstu (wspólnotowego, kulturowego) i wciąga na listę swoich fetyszy, stając się symbolem wieloznacznym (Srp 2001: 53). Ponadto monumentalizuje detale, robi zbliżenia, tło pozostaje zagadką. Przedmioty izolowane z całości stają się głównymi bohaterami fotografii. widzimy więc: stare i zniszczone rzeczy (odrapane, popękane czy popisane elewacje domów, pomnik pochlapany farbą, zdarte plakaty czy obrazy), przedmioty, które wyszły z mody i są binarne. Artysta traktuje czas jako element wnikający do wnętrza przedmiotów, tematyzując $\mathrm{w}$ ten sposób problem przemijania i zanikania (Srp 2001: 53). Ten motyw należy szczególnie do fotografii, na których przedstawione są funeralia: trumienki dziecięce, pomniki cmentarne, krzyż leżący na ziemi, zatarty nagrobkowy medalion ze zdjęciem kobiety. 
Tekst Heislera wydaje się korespondować z tym, co sfotografował Štyrský. Obiekty przez niego kreowane są niejednokrotnie personifikowane, przejmują zadania podmiotu:

Szmaciany motyl przelatuje z przemieści na przedmieścia i żółte światło lamp gazowych przysiada $w$ jego rozbitych skrzydłach (...) (Heisler 1999a: 112).

(...) i wyrzuty sumienia wdzierają się beznadziejnie w przedmioty (Heisler 1999a: 104).

Czas jest nieokreślony i chaotyczny. Istnieje jakieś „teraz”, „przeszłość” i ,przyszłość”, aczkolwiek nie są one chronologicznie uporządkowane, co więcej, opisywane wydarzenia, chociaż należą do jednej kategorii czasu, niosą ze sobą sprzeczne informacje, często wykluczają się. Sam tekst nie ma konkretnej fabuły, jest zbiorem obserwacji, rodzajem strumienia świadomości bez narratora. Niepewnością dodatkowo napawa fakt niemożności określenia czasu i przestrzeni, wydarzenia opisane w tekście mogłyby się wydarzyć zawsze i wszędzie, czyli nigdy i nigdzie. W poniższy sposób Heisler konstruuje narrację o przyszłości:

(...) w urodzajnych polach rozległej przyszłości (Heisler 1999a: 120).

A przecież północ będzie głęboko oczywista (Heisler 1999a: 102).

Ogień, dziś tak pieczołowicie zamknięty, szeroko się otworzy i pójdzie z ręki do ręki (Heisler 1999a: 144).

I przecież przebieg dnia będzie tak głęboko oczywisty, że człowiek nie spotka zakonnicy ani żołnierza (Heisler 1999a: 116).

$\mathrm{Na}$ szczególną uwagę zasługuje poruszający fragment, którego metaforyka ukazuje doświadczenia związane z deportacją ludności do obozów koncentracyjnych podczas drugiej wojny światowej. Szare transporty, ołowiany ogródek, a na końcu przeżywanie ostatniej godziny przed białym wzrokiem ognia; wszystkie te elementy stają się przedmiotem refleksji, zwłaszcza w kontekście żydowskiego pochodzenie Heislera.

Popatrzcie na zewnątrz, gdzie dzwonią żałobne dzwony, deszcz gromadzi się nad szarymi transportami, w których porusza się mięso w proszku, jak mak w makówkach kołyszących się na wietrze i ubierajcie się, ubierajcie się, żebyśmy opuścili ten ołowiany ogródek, który skrzypie, jeszcze obciążony wspomnieniami przeszłości i przeplatany gnijącymi kawałkami drewna, przeżywa swoją ostatnią godzinę przed białym wzrokiem ognia (Heisler 1999a: 132). 


\section{Flaneur - motyw przechodnia}

W niektórych przedstawieniach melancholii głównym aktorem staje się przestrzeń, często miasto. Motywem czerpiącym z przestrzeni jest Baudelaire'owski Flâneur włóczęga, spacerowicz po Paryżu, baczny obserwator. Nie ma on żadnego celu w swojej tułaczce: podziwia witryny sklepowe; nie wchodzi jednak do żadnego butiku, gubi się wśród wąskich uliczek, roztrząsa fakt, że miasto ciągle się zmienia, popada w nostalgię z tego powodu (Bieńczyk 2012: 12-16). Postawa ta jest często ukazywana w heterotopiach, rozumianych jako przestrzeń (miasta), wielowarstwowych semantycznie, które są niepokojące, przeobrażają się, stają się niemożliwe do nazwania z powodu procesów przemian (Foucault 2005: 19). Poszukiwania całości w tym chaotycznym, fragmentarycznym mieście skazane są na niepowodzenie (Bieńczyk 2012: 12-16). Jednym z wielu tematów melancholii jest koszmar powtarzania. Cykl Na jehlách těchto dni miał przypominać spacer $\mathrm{w}$ celu fotografowania obiektów znalezionych, czyli przedmiotów należących do osobistego semantycznego zbioru wspomnień, snów i skojarzeń artysty. Przestrzeń będąca aktorem tego przedstawienia niczym jednak nie zaskakuje, jest monotonna, chora i chaotyczna.

\section{Żałoba i niemożność przeżycia straty}

Niemożność przeżycia straty oraz uporczywe, dobrowolne trwanie w stanie żałoby jest jedną z cech nie tylko utworów z motywem melancholii, ale także jednym $\mathrm{z}$ tematów szeroko rozwiniętych przez estetykę surrealistyczną. Koncepcja obiektów znalezionych, poszukiwanie skojarzeń i znaczenia snów w podświadomości człowieka, powrót do dzieciństwa, fetyszyzacja obiektów; właściwie wszystko to, co surrealizmowi przyniosły związki z psychoanalizą, opiera się na dialektyce doświadczenia przeszłości, a często nawet fiksacji na jej punkcie. Przykładowo, literackie i plastyczne dzieła Štyrskiego z bohaterką Emilią są efektem ciągłego rozpamiętywania ukochanej Marii, przyrodniej siostry, która zmarła w młodym wieku. Doświadczenie to już zawsze towarzyszyło artyście, co w twórczości obrazował przez łączenie miłości ze śmiercią (Woźniak 2015: 19).

W utworze Na jehlách těchto dní Heisler rozpamiętuje utracenie całości, która się rozpadła wraz z nastaniem wojny oraz spokoju, które zmąciło niebezpieczeństwo. Motyw ten ukazywany jest w sztuce jako procesy metamorfoz, często jako rozczłonkowane ciała, które poskładane są z różnych elementów, żyją, aczkolwiek jest to życie niepewne, kruche i nienaturalne. 
Pani widok umiera $\mathrm{z}$ nadzieją na przytulenie. Tylko słońce stopniowo dotyka wypielęgnowanych mięśni, które nie niosą ani deszczu, ani wiatru, ani ciepła w Pani łóżku (Heisler 1999a: 96).

\section{Wnioski}

Prawdopodobnie teksty surrealistyczne nie były tworzone z zamiarem odzwierciedlenia melancholii, a jednak badacze tego zjawiska posługują się podobnymi narzędziami do opisywania przestrzeni i nadają nowe motywy, być może niedostrzeżone przez wcześniejszych badaczy surrealizmu. Można się przychylić do przekonania, iż w większości czeskich surrealistycznych utworów z czasów międzywojnia oraz drugiej wojny światowej, przeważa zaniepokojenie ówczesną sytuacją polityczną, doświadczenie wojny i przemocy. Te przeżycia sprawiają, że człowiek chce powrócić do przeszłości, która wydaje się mu być bezpieczna i szczęśliwa. Odkrywa jednak, że proces ten nie przynosi mu szczęścia i spełnienia, co więcej, rozczarowuje go; wspomnienia uległy zatarciu, a przeszłość z dzisiejszej perspektywy okazuje się być inna: krucha, niepewna i nietrwała. Te procesy, tak charakterystyczne dla wielu nadrealistycznych utworów, powodować mogą przygnębienie, rezygnację, wprawiać w melancholijny nastrój.

Z pewnością dla estetyki melancholii i surrealizmu punktami wspólnymi są: niemożność przepracowania straty, dłużący się czas żałoby wynikający z odmowy porzucenia uporczywych myśli o swoich fetyszach, niepewny status całości, z których wynikają wyliczenia i związane z nimi metamorfozy obiektów, a także ukazanie przedmiotów jako aktorów i obserwatorów życia człowieka. Badany cykl jest po części melancholijny; jednak mimo wyrażonej niepewności dotyczącej przyszłości Heisler przejawia nadzieję, na lepszą przyszłość. Pojawia się wiele widocznych elementów melancholii w tym badanym tekście wizualnym, aczkolwiek należy pozostać przy stwierdzeniu, że mimo wielu punktów wspólnych estetyka surrealizmu i melancholii nie jest równoważna.

\section{Summary}

The article presents the surrealistic avant-garde work Na jehlách těchto dní by Jindřich Štyrský and Jindrrich Heisler in the context of melancholic aesthetics: the flâneur concept, specific discontinuity of time and space, inability to grieve, constant searching for integrity, and construct of enumerations. Analysis leads to the conclusion that surrealism and melancholy motives are very similar to each other, but they are not identical. 
Motyw melancholii w czeskiej awangardowej poezji wizualnej na przykładzie utworu Na jehlách těchto dní Jindřicha Heislera i Jindřicha Štyrskiego

\section{Shrnutí}

Příspěvek uvádí surrealistický avantgardní cyklus $N a$ jehlách těchto dní Jindřicha Štyrského a Jindřicha Heislera v kontextu estetiky melancholie: konceptu flâneur, specifického vnímání diskontinuity času a prostoru, neschopnosti prožití smutku, neustálého pátrání po celku, a využití enumerace. Analýza textu a fotografií vede k závěru, že motivy surrealismu a melancholie jsou velmi podobné, ačkoliv nejsou identické.

\section{Literatura}

Bieńczyk, M. Melancholia. O tych co nigdy nie odnajda straty. Warszawa: Świat Książki, 2012.

Foucault, M. The order of things. London-New York: Taylor and Francis e-library, 2005.

Heisler, J. Na jehlách těchto dní. In: Heisler, J. Z kasemat spánku. Praha: Torst, 1999a, s. $83-147$.

Heisler, J. O ilustraci, která není ilustrací. In: Heisler, J. Z kasemat spánku. Praha: Torst, 1999b, s. 309-311.

Małczyńska, A. W kręgu melancholii. Fragmenty historii. In: Małczyńska, A., Małczyński, B. (eds.) W kręgu melancholii. Opole-Wrocław: Chiazm, 2010, s. 9-22.

Srp, K. Jindřich Štyrský. Praha: Torst, 2001.

Woźniak, K. Wtajemniczenia. Szkice o motywach inicjacyjnych w prozie czeskiej XXw. Wrocław: Universitas, 2015.

Vojvodík, J. Świat strachu i strach przed światem w czeskim surrealizmie lat 30. i 40. Teksty Drugie. 2007 (6), s. 50-77. 